\title{
ROLE-PLAY AND SHOW-AND-TELL IN GRADE 5 STUDENT'S SPEAKING LEARNING
}

\author{
Choiril Anwar \\ Universitas Islam Sultan Agung \\ choirilanwar@unissula.ac.id
}

\begin{abstract}
This research was conciously intended at investigating the following: (1) the effectiveness of role-play and show-and-tell and (2) which one was more effective between role-play and show-and-tell in grade 5 students' speaking learning. It was a quasi-experimental study by implementing the research design of randomized pretest-posttest control group. The data were collected by a non-test of an observation. The instrument of the research was observation sheets completed by speaking rubric on Likert scale. Those data were then analyzed by using one-way ANOVA followed by the Scheffe test. The results of the research showed that: (1) role-play and show-and-tell were effective in grade 5 students' speaking learning indicated by $p<0.05$ and; (2) role-play was more effective than show-and-tell indicated by $p<0.05$.
\end{abstract}

Keywords: Speaking, Role-play, Show-and-tell

\section{INTRODUCTION}

Learning English is definitely urgent nowadays. English is still important becuase it is a popular language and has been frequently regarded as a global language. It is the most commonly used language among foreign language speakers. Furthermore, it plays an important role at all aspects of society. It is such an international language which is compatible for diplomacy, banking, computing, medicine, business, science, technology, aviation and many other branches in current people's issues. English speakers are required at almost all departments or offices. Since this is a global language, many people commonly use English to communicate to one another when they from various backgrounds of country come together. Therefore, learning and mastering it can give lots of advantages to the learner.

In Indonesia, as a foreign language, English is taught to students at almost all levels of education. At kindergarten and primary schools, students get English language as a local content or an extracuricular. At high schools, 
even at university, English language is a compulsory material to be learned by the students. The result, however, is still considered quite unsatisfactory.

There are some reasons why the English teaching have not produced good outputs. One of the reasons is that the purpose of language learning so far has not been to enable students to apply English in their real communication orally. This can be seen from the speaking skills of many Indonesian students at any level of education, moreover in elementary schools. Most of elementary school students still find it hard even in producing simple short expressions such as those which are utilized in asking for help, giving information, expressing gratitude, invitation, describing objects or people and many other short functional usages.

English, as other languages in the world, is actually for communication. It means that it is surely something to do with how someone utters words in spoken expressions. At the same time, globalization urges people to be able to interact with foreigners. So it is a must for someone living in this era to have a good speaking skill so that he or she can interact with others even foreigners more confidently. This idea therefore can come true if the learning of speaking skills begins from primary schools.

The problem found by the researcher in reality was that so many students of elementary schools in Yogyakarta, as they were in SD Budi Mulia Dua Yogyakarta, could not speak English well. Most of them were not confident enough for practicing speaking. They were not quite brave for making mistakes when they were asked to speak up even a bit in the classroom. Actually some of them were confident but not good in pronunciation and lack vocabularies.

In short, it can be said that most of students of elementary school have minimum motivation to speak English because the English materials themselves have not been taught in pleasant and interesting ways. Therefore, there must be effective techniques to motivate elementary school students to first love English better, to be more confident and, more significantly, to be able to speak English well. It means that with these techniques, the students hopefully can speak in a better pronunciation with rich vocabulary and more fluently than before. 
Thus in this study, the researcher observes based on some supported theories, pre-survey, and the researcher's experiment when teaching English in elementary schools that role-play and show-and-tell are both adequately effective techniques in the speaking skills learning of elementary school students. In other words, these techniques can attract students to speak a lot.

There are several reasons why the researcher finally chose role-play and show-and-tell as the techniques to investigate in the learning of speaking skills of grade 5 students of SD Budi Mulia Dua Yogyakarta. Role-play, beside it is enjoyable and exciting, is a communicative technique which possibly "develope fluency and pronunciation of students' language, promotes interaction in the classroom, and even increases student's motivation" (Ladousse, 2000).

Whereas show-and-tell can provide more chances for English learners to seek for and construct meaningful interactions as they make sense of their world and represents their learning through spoken languages. Furthermore, it "provides opportunity to develop expressive language as children learn to create and construct language" (Dailey, 1997). In addition to that, role-play and show-and-tell factually have not ben taught in many chances in the learning of speaking skills of grade 5 students of SD Budi Mulia Dua Yogyakarta. Therefore, the researcher then is convinced that by implementing these techniques, the problems of elementary school students especially in speaking skills can be overcome. The researcher then finally prefered to focus on investigating the effectiveness of using role-play and show-and-tell in the speaking skills learning of grade 5 students of SD Budi Mulia Dua Yogyakarta.

This study was formulated into two questions as follows: (1) Is the use of role-play and show-and-tell effective in the speaking skills learning of grade 5 students? (2) Which one is more effective, role-play or show-and-tell in the speaking skills learning of grade 5 students? This study was therefore aimed to find out whether the use of role-play and show-and-tell are effective or not and which one is more effective between those two techniques in the speaking skills learning of grade 5 students of SD Budi Mulia Dua Yogyakarta.

This study was hopefully to be then profitable for the following parties: For Students, they will hopefully experience a more comfortable learning 
situation, which will be able to improve their motivation to produce English orally, in which it will possibly help them improving their speaking ability. For Teachers, tt will possibly give more insights in presenting materials in their teaching process. It also gives an alternative technique for them to improve their students' speaking performance. For schools, it will give such a better reference for schools so that they may ask their teachers to practice the approaches that are fit and suitable to be used for the school to enhance qualified outputs.

There are some important theories regarding with this research described to strengthen the understanding or knowledge of topic being studied. Brown and Yule (Nunan, 2005) state that "spoken language consists of short, often fragmentary utterances, in a range of pronunciations". There is frequently a great deal of repetition and overlapping between one speaker and another, and speakers tend to use non-specific references. Whereas Nunan (Brown, 2001) claims that speaking skills consist of monologue and dialogue speaking skills. Monologue speaking skills are speaking skills of one-way communication such as news host. Dialogue speaking skill here is a two-way communication such as interview. The monologue is divided into planned monologue and unplanned or spontaneous monologue while the dialogue is divided into interpersonal and transactional. Interpersonal dialogue is aimed to gain social relationship, while transactional dialogue is aimed to expressing a message atau factual information. Interpersonal and transactional dialogue consist of two categories, namely familiar and unfamiliar dialogue.

After all, speaking skills have something to do with principles of a communicative view of language. In this case, Richards \& Rodgers (2001) in McDonough \& Shaw (2003) offer four characteristics of a communicative view of language as follows:

Language is actually a system for expressing meaning; The primary function of language is for interaction and communication; The structure of language reflects its functional and communicative usages; and the primary units of language are not merely its grammatical and structural features, but categories of functional and communicative meaning as exemplified in discourse. (McDonough \& Shaw, 2003)

Harmer (2003) claims, "The fluent speaking skill is not only a knowledge of language features, but also the ability to process information and 
language 'on the spot"'. It can be stated shortly that if individual has fulfilled the whole criteria of these two elements of speaking, both knowing the knowledge of language features and having social/mental processing in social life, he or she will have capability to speak up more fluently than before. Tsang and Matilda (Richards \& Renandya, 2002) argue that there are four potential characteristics of conversation in classroom. Such characteristics are 1) collecting vocabulary as the resource of conversation, 2) using an opening of conversation which expresses an idea, makes a message, or describes a fact to attract real communication, 3) training students' conversation repeatedly to minimize an error, and 4) repeating the conversation intensively, actively involving students in the learning process.

According to Rivers (1983), speaking skill's learning urges the teacher to be more flexible. It means that the teacher must have capability to arrange several stuffs that never been done before. The teacher's flexibility consists of four things, namely 1) be flexible for the students' attitude and the change of curriculum, 2) be flexible for the formats of learning activity in the classroom, 3) be flexible for the approach and methodology used, and 4) be flexible for the approach used to improve the students' achievement. Whereas Paulston and Bruder (1976) state that the teaching of speaking skill is not apart from the thought of teaching oral skills. It is the result of a speaker's competence to communicate in target's language. Brown (2004) has divided the types of speaking skills' learning, as it is in listening, into five taxonomies. Those five taxonomies include imitative, intensive, responsive, interactive, and extensive.

According to Harmer (2003), there are six activities in the learning of speaking skills: They are acting from a script, communication games, discussion, prepared talks, questionnaires, and simulation and role-play. In assessing language skills, Brown (2004) has divided the assessment into two divisions, those are microskill and macroskill assessment. Microskill assessment is something to do with small parts of language such as phoneme, morpheme, words, collocation, and phrase units. Whereas macroskill assessment is something to do with bigger components as fluency, discourse, function, style, cohesion, nonverbal communication, and chosen strategy. Moreover, microskill and macroskill assessment of speaking have their own 
different objectives based on their features. To assess speaking skills, Brown (2001) divides it into six categories, namely grammar, vocabulary, comprehension, fluency, pronunciation, and assignment.

The teaching of elementary school students is surely something to do with teaching young learners. Young learners or children I mean in this paper are those between five and twelve years of age. So in teaching them, teacher must understand deeply the characteristic of young learners generally.

When teachers know and understand well their young learners' characteristics, they at least will know what to do best regarding the speaking instructions in the classroom. Furthermore, in teaching English to young learners, a teacher must consider some principles (Ellis \& Brewster, 2002) as summarized below.

First, children are excellent observers and have a natural ability to grasp meaning in their L1 from a variety of sources. Teachers then can help them drawing on this skill in the L2 by ensuring language use is contextualized and has visual support as good as possible. Second, children learn L1 often by repeating words and phrases in order to become completely comfortable with their sounds and meaning. Incorporating repetition, therefore, is important but teachers must be guided by the children's reactions to know when it is enough. Third, children are "trained" at guessing and predicting and teachers can usefully draw on these skills and the other thought processes outlined as part of 'learning to learn'. Fourth, children like to talk, even if they do not know much language, often with only two or three words as well as key intonation patterns. Teachers in scuch a case should try to provide opportunities for meaningful communication activities whatever possible. Fifth, when learning L1 children seem to be good risk-takers and experimenters. Their willingness to 'have a go' should be encouraged and should not be dampened too much by constant correction or an overly strict atmosphere. (Ellis \& Brewster, 2002)

Paul (2003) adds two principles considered by those who teach English to children particularly in Asia. The priciples were humanistic and constructivist approaches. In a humanistic approach, effective learning takes place when children are fully involved in the process of learning as "whole" individual people, making real choices, learning in meaningful contexts and in anxiety-free environment. Whereas constructivist approaches focus on the child as an individual trying to make sense of the world in which she finds herself. By nature, a child is an active learner.

Part of the magics of teaching young learner a foreign language is in their unspoken assumption saying that foreign language is just another way of expressing what they want to express, but there are limitations because they 
lack actual language. Children will also often naturally insert their native language when it is really hard for them to find the English words.

Cameron (2001) states that there are two "guiding principles" for teaching speaking for young learner. First, meaning must come first. As stated in theories of development by Piagetian and Vygotskyan that children actively construct meaning from their experiences in the world. From early childhood, the desire to connect emotionally and communicate with other people seems to drive speaking. As "children move through infancy, they begin to communicate with others about things in their shared world, and develop their vocabulary of labels alongside their developing abilities to categorize" (Locke, 1993) in Cameron (2001). So, if children do not understand the spoken language, they cannot learn it. Second, to learn discourse skills (use the language), children need both to participate in discourse and so build up knowledge and skills for participate. In this case, a good teacher of spoken language must ask students to take part actively in some activities so that they can build up their knowledge from those activities.

What is important with beginners is finding the balance between providing language through controlled and guided activities and at the same time letting them enjoy natural talk. Teacher can ask students to have little opportunity to practice speaking English outside the classroom and so need lots of practices when they are in class. In this stage, the teacher should correct at once as seeing pupils making mistakes working with controlled and guided activities.

To figure out the role of role-play in teaching and learning speaking, it is better to know deeper first about the definitions of role-play and show-andtell in the learning of speaking skills. Role-play is an activity in which people act a situation; It is used especially in training people to develop communication skills or in treating mentally ill people (Hornby, 1995). Whereas Ladousse (2000) states that when students 'role', it means that they play apart (either their own or somebody else's) in a specific situation. 'Play' means that the role is taken on in a safe environment in which students are as inventive and playful as possible.

According to Harmer (2003), 
Role-play is studentse simulation of a real-life encounter (such as a business meeting, an encounter in an airplane cabin, or an interview) as if they were doing so in the real world, either as themselves in that meeting or aero plane, or taking on the role of a character different from themselves or with thought and feeling they do not necessarily share. Role-play encourages the student to be actively participating in teaching learning process because this method provides a way of creating a rich communicative environment where students actively become a part of some real word systems and function according to predetermined roles as members of that group. In conclusion, these are caused by the method variation developed and used by the English teacher that the students feel bored and dislike the speaking subject in the class.

Role-play does not only make students active but also imaginative and critical. Role-play stimulates real life situations and practical setting. In roleplay, students can bring items to the class to make a practical setting. For instance, if a student is playing a role as an announcer, she brings a script to read as an announcer. So, it is appropriate to use role-play in improving student's speaking skill.

Harmer (2003) states that role-plays will be effective if "they are openended, so that different people will have different views of what the outcome should be, and a consensus has to be reached. There is a dynamic movement as the role-play progresses, people are clearly motivated to say as much or as little as they need to achieve their aims."

Shaftel (1967) in Joyce, Weil, \& Calhoun (2009) argues that role-playing consists of nine steps as the following: warming up the group atmosphere, choosing the participants, organizing the place, preparing the researcher, role playing, discussion and evaluation, re-role playing, discussion and evaluation, sharing and developing experience. Each step has specific purpose that will increase the "richness" of the this model result and help the students to be focused on the learning activity.

Based on the whole theories above, the writer tries to find the effective solution to increase the speaking mastery of the fifth grade students by employing role-play as a technique of teaching speaking, which is the subject the research.

Whereas show-and-tell (Walter, 2008) means "a school activity for young children in which a child brings an object into the class and talks to the other children about it." Almost the same as it is stated by Walter, 
www.thefreedictionary.com. updated in 2009 by Houghton Mifflin Company also stated that Show-and-tell means an educational activity in which a child displays an object to the class and talks about it, or it also means a public presentation or display. Whereas in Random House Kernerman Webster's College Dictionary (2010) it is stated that show-and-tell is (1) a classroom activity for young children in which each child produces an object and talks about it, or (2) any informative presentation or demonstration.

Raines \& Canady (1990) in Dailey (1997) state that "show-and-tell can provide an opportunity for learners to seek and construct meaningful communication as they make sense of their world and represent their learning through spoken language." Whereas Goodman (1986) in Dailey (1997) claims that "show-and-tell provides an opportunity through which language is made easy. Language focuses on the meaningful whole while empowering the learner to use language in meaningful contexts that are an outgrowth of the language learning used in the home."

From all definitions mentioned above, it can be stated that show-andtell is an activity done by young children whom they bring an object based on the topic of the learning into the class and talk to the other children to about. It also means any informative or public presentation or demonstration meaning that they show something and want others to know about it. In addition to that, show-and-tell has several advantages included it provides an opportunity to develope meaningful and expressive language since children used to learn for creating and constructing meaning. Those definitions, after all, are in line with the research.

Show-and-tell, dealing with the learning of speaking, students in this case will show what they bring from home and then they will try to describe the objects to others in the classroom. To make a better speaking, the students are able make a good preparation for having good performance in front of their classmates. To make it more exciting, teacher can ask other students to ask questions to the performer. So in this activity, students are conditioned to be more active. They can ask questions such as where the objects bought from are, when the student get the objects, and so on. So by telling in longer talk, 
students will get used to talk and speak. Inevitably, their speaking skills will have improvement for sure.

Review of Related Research Studies

First, the research done by Supartinah (2010) entitled The Effectiveness of Applying Role-Play and Telling Picture Story Technique to Improve Javanese Speaking Skills of Grade V Students in SDN Lempuyangan Yogyakarta. This was an experimental research study which investigates the effectiveness of role-play and telling picture story in the efforts to improve elementary school students' javanese speaking skills. The result of this research indicated that role-play was the most effective technique compared with both picture series telling and lecturing technique in the learning of the javanese speaking skill among the students of the complex of SDN Lempuyangan Yogyakarta.

Second, the research done by Ratminingsih (2010) Drills and Total Physical Response: An Attempt to Enhance Young Learners' Oral Communicative Competence. The result of the study indicated that the use of Drills and TPR could improve the students' oral communicative competence. At the same time, both techniques could also improve the students' ability in using the language aspects, such as vocabulary, grammar, pronunciation, fluency, and comprehension which should be dealt with in speaking.

Third, the research done by Aini, Andayani, and Anindyarini (2012) entitled Mind-Mapping Method to Improve the Speaking Skills of Elementary School Students. The result of the study indicated that mind-mapping method could increase the quality of speaking skill learning, both being active or the result, of fourth grade students of Karanganyar 1st State Elementary School. The increasing of being active was indicated by the acquisition of being active percentage that could be seen by four aspects. There were asking if there was something unknown, answering or giving feedback, caring of teacher's explanation, and staying on their own chair.

Frame of Thought

Speaking skill as a means to interact with others, can be learned by learning English. In order to have an effective learning in speaking, a variative and effective technique must be applied as well. To know that the learning 
techniques of speaking at school so far still needed improvements. They were still monotonous and lack of variations so that the quality of the students' speaking skills was still limited. Such a problem seemed from the classroom activities in which there were only some students who are active in joining the learning and teaching process. Besides, most of teachers did not apply the learning technique in which they only use the materials and tasks from the textbooks which must be bought also by the students.

Based on some theories, survey, and the researcher's experiences, the researcher then was convinced that role-play and show-and-tell were effective techniques to apply in the speaking skills learning of grade 5 students of SD Budi Mulia Dua Yogyakarta. Both techniques were considered as playing a good role for bringing about a maximum learning of speaking because they use more of physical and oral activities. However, practically those techniques are rarely used in elementary schools, as it is in SD Budi Mulia Dua Yogyakarta.

These techniques actually have their own features in the components and the involvements. Role-play can activate students' speaking skills through playing the role of characters and involve other students to talk one another in dialogues. While in show-and-tell, it urges students to speak a lot but it does not need other students to be partners to talk.

Above all, the researcher observes and then hypothesizes that role-play technique is more effective than show-and-tell technique in the speaking skills learning of grade 5 students of SD Budi Mulia Dua Yogyakarta. Such a hypothesis is taken by considering the theory on elements of speaking by Harmer (2003) as explained in the theoretical review above that "the ability to speak fluently presupposes not only a knowledge of language features but also the ability to process information and language 'on the spot"'. Based on this theory, the researcher then thinks that role-play matches both requirements.

Therefore, a research should be done to investigate whether those two techniques are both effective or not and which one is more effective between those two techniques in the learning of speaking skills of grade 5 students of SD Budi Mulia Dua Yogyakarta. 
In doing this study, the researcher hypothesized that (1) the use of roleplay and show-and-tell is effective in the speaking skills learning of grade 5 students and role-play is more effective than show-and-tell in the speaking skills learning of grade 5 students.

\section{DISCUSSION}

This is a quantitative research with a method of experimental design, that is randomized pretest-posttest control group design (Campbell \& Stanley, 1966). In this design, according to Fraenkel \& Wallen (2008), two groups of subjects are used, with both groups being measured or observed twice. The first measurement serves as the pretest, the second as the posttest. Random assignment is used to form the groups. Random assignment is the process of assigning individuals at random to groups or to different groups (Creswell, 2008).

In this research, the researcher uses role-play $\left(\mathrm{X}_{1}\right)$, show-and-tell technique $\left(\mathrm{X}_{2}\right)$, and lecturing or conventional technique $\left(\mathrm{X}_{3}\right)$ as the independent variable. Whereas the dependent variable is speaking skills ( $\mathrm{Y}$ ). Role-play and show-and-tell techniques are those of the experimental groups while lecturing technique is the control group. Such three groups are determined randomly by the researcher. Randomization is a procedure with which to reduce the amount of systematic error that might result from biases in the assignment of subjects to group besides providing better control of variables that could affect internal validity (Seliger $\&$ Shohamy, 1989).

Those two different groups (experimental and control group) then are examined by pretest and posttest to know the condition whether there is a different effectiveness of using role-play and show-and-tell in the speaking skills learning of grade 5 students of SD Budi Mulia Dua Yogyakarta. Moreover, this is also to find out which one is more effective between role-play and show-and-tell in improving the grade 5 students' speaking skills.

In the time between the pretest and posttest, some treatments are given to the experimental groups, while there is no treatment using those of two 
techniques for the control group. The research design can be seen in the table 1 below:

Table 1. The Randomized Pretest-Posttest Control Group Design

\begin{tabular}{cllllll}
\hline Experimental Group 1 & $\mathrm{R}_{1}$ & $\mathrm{E} 1$ & $\mathrm{O}_{1}$ & $\mathrm{X}_{1}$ & $\mathrm{O}_{2}$ \\
Experimental Group 2 & $\mathrm{R}$ & $\mathrm{E} 2$ & $\mathrm{O}_{3}$ & $\mathrm{X}_{2}$ & $\mathrm{O}_{4}$ \\
Control Group & $\mathrm{R}$ & $\mathrm{C}$ & $\mathrm{O}_{5}$ & -- & $\mathrm{O}_{6}$ \\
\hline (Campbell \& Stanley, & $1966)$
\end{tabular}

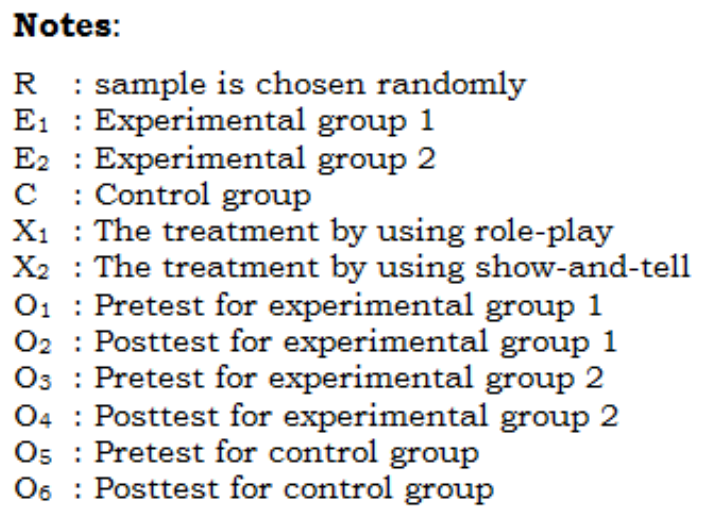

The experimental design above describes that there are three sample groups: two groups as the experimental groups and one group as the control group. Experimental group and control group have a pretest of speaking skills, then they are examined to find out the difference among them to acquire the condition like in the beginning. In the final treatment, the researcher will see the difference between the pretest and posttest of experimental groups and the difference between the pretest and posttest of control group. And then the posttest result of experimental groups are compared with the posttest of control group by using Scheffe to find out which one is more effective technique between experimental group 1 and experimental group 2 in the speaking skills of grade 5 students.

Whereas in the process of research, the reseacher does several steps included as follows: (1) Pre-survey and asking permission to schools in dealing with the research, (2) developing learning strategies while considering the syllabus and the lesson plan with the English teachers in the experimental groups, (3) making the research instrument, (4) validating the instrument by inviting an expert to give judgments (expert judgment), (5) doing try-out for the 
instrument, (6) doing pretest, (7) doing experiment/treatments, (8) doing posttest, (9) analyzing the data, (10) reporting the results, and (11) making conclusions and suggestions.

Place and Time of the Research

This research was done in SD Budi Mulia Dua Seturan Yogyakarta. The reason why chosing this school was that role-play and show-and-tell have never been used in many chances in the teaching and learning process especially in the purpose of improving the grade 5 students' English speaking skills. In addition to that, students of SD Budi Mulia Seturan Yogyakarta, even the fifth graders, tent to be more active in the learning process than other students of elementary schools. Those reasons were also the factors to apply these techniques in their speaking skills learning.

The researcher had done a pre-survey for two months in August September 2012 while the research itself had been done for 3 months in April - June 2013 or in the second semester of academic year 2012-2013.

Population and Sample of the Research

The population of the study was all grade 5 students of SD Budi Mulia Dua Yogyakarta. They are 187 students in total. As the information that Budi Mulia Dua Foundation had three locations of elementary school. They are SD Budi Mulia Dua Seturan (116 students), SD Budi Mulia Dua Pandeansari (28 students), and SD Budi Mulia Dua Sedayu (43 students).

The experimental group and control group samples were determined randomly. Such a randomization was to avoid the researcher's subjectivity.

The research samples were 26 students of grade 5 Minangkabau, 26 students of grade 5 Sriwijaya (as the experimental groups), 27 students of grade 5 Cirebon (as the control group), and 30 students of grade 5 Demak as the group to try out the instrument. So, the samples were then 120 students in total. They were all from SD Budi Mulia Dua Seturan.

Variables

The variable in this research is related to the identification of variable and the definition of variable operational. In this research, the independent 
variables are role-play technique, show-and-tell technique, and lecturing technique. While the dependent variable is grade 5 students' speaking skills.

To avoid various assumptions on the terms of the research variables, the researcher then tries to explain each variable operationally as follows: Role-play is a kind of technique to improve student' speaking skills by showing dialogues, attitudes from character determined to create imagination which is able to describe a certain event. Show-and-tell is the technique to improve speaking skills by showing things students like to other students and the teacher. Lecturing is teacher' technique in delivering the material by explaining concepts, principles, and facts to the students in classroom. In the end, there is a session of asking and answering questions from the teacher. Speaking skills here are students' competences in delivering their thoughts and opinions orally.

Procedures

This experiment research was planned to pass these three procedures. They were pre-experimental, experimental, and post-experimental plans.

The teachers who helped researcher doing the experiment were English teachers of SD Budi Mulia Dua Seturan. They were Sari Wulandari and Emi Prihastuti. The classes of experimental groups and control group was mostly handled by those English teachers. While the researcher was only as the observer of all activities regarding the research in the school. Therefore, researcher trained first the teachers so that they would know the procedures for doing the experiment as what researcher had planned before. This is also be able to avoid misunderstanding between the researcher and the English teachers in giving treatments.

The learning material given to students was in line with curriculum made the English teacher from some guided books such as Grow With English 5 published by Erlangga, Speed Up English 5 published by Yudhistira, Let's Talk, and so forth.

Experimental preparations to do dealing with the experimental group and control group were by (1) determining the research sample by simple 
random sampling technique to find students who will be used for the research, (2) doing homogeneity test to both groups based on the pretest result, and (3) writing down/making lesson plan. The lesson plan was appropriate with the experiment whether the class was the experimental group 1 for role-play or experimental group 2 for show-and-tell and control group for lecturing technique by the English teacher as usual.

An experiment is said as qualified if the result required is only because of the independent variable manipulated and if such a result can be applied on the situation outside the research environment. The two conditions to fulfil were internal validity and external validity.

Wiersma and Jurs (2009) explain that "internal validity represents as the validity of the cause-and-effect inference linking the independent variable and the dependent variable." It underlines whether the experimental treatment really makes a difference in the dependent variable. To answer this question, the researcher must be convinced that the factors as extraneous variables have been controlled and do not produce an experimental treatment effect.

Those things, therefore, were controlled dealing with the internal validity in this study refer to what stated by Campbell and Stanley (1966).

The controlling was done by giving questions for the same scoring and holding the scoring in the same time. The researcher gave the students time to share anything orally based on their own experiences. Another controlling was done when the researcher did the long experiment for 12 times of meeting.

The Instrument

The controlling was done by guided scoring sheet of speaking performance which was valid and reliable. The scoring process was done carefully based on the rubric determined.

The Material of the Treatment

The material was developed from the same curriculum, standard of competence, and basic competence. The controlling was done by determining the same objective of learning.

Contamination of Inter-subject of the Experiment 
The controlling was done by observing and making the score of students' speaking skills in each learning treatment activity, both to the experimental group and the control group.

Experimental Mortality

The controlling was done by exceeding the sample. All students in the research groups were treated equally, both to experimental and control group but only 30 students considered. However, in fact there were several students who were absent in some treatments and some students resigned from the group so that only 26 samples of students who were in experimental group 1 , 26 ones in experimental group 2, and 27 ones in control group considered to anticipate unpredicted results.

Implementation

The controlling was done by developing lesson plan based on the experiment planning, holding a meeting with English teacher for coordination, giving such training to the English teacher and keeping an eye on her in the learning and teaching process.

External Validity

External validity deals with the generalizability of the results of the experiment. Generally, "the more extensively the results can be generalized the more useful the research, assumed that there is adequate internal validity" (Wiersma \& Jurs, 2009).

In this research, the controlling of external validity was done by observing whether the finding results can be applied in other conditions. For getting the external validity, the things bothering to achieve such a validity could be controlled by determining the appropriate time of experiment to anticipate the unwanted things outtrack of setting happened in the research. This validity is the controlling of representiveness of research finding to be generalized to the research population. Therefore, the external validity was done in this research in which the population was controlled by (1) taking the sample in accordance with the characteristic of the research population, and 
(2) doing randomization when determining the subject of research that will get the treatment.

To know the effect of ecology validity, the controlling was done by (1) not informing to the students that they become the subject of research, (2) not changing the schedule of the lessons made by the school, (3) the learning or experiment or treatment was done by the english teachers of the experimental groups and control group, and (4) the controlling of the treatments was done by the researcher by observation. By controlling the external validity, hopefully the research findings found were really the result of the treatments given by the English teachers in the learning process.

Data Collection Technique

The data of students' speaking skills in the research were collected by observation, namely observing the students' speaking performance with guided sheet of observation and scoring sheet of students' speaking performance.

The scoring sheet of speaking performance in this research was used to know the students speaking skill of SD Budi Mulia Dua Seturan Yogyakarta after they were treated. Performance scoring was made twice, those were before and after the treatment.

Observation sheet was used for keeping an eye on the classroom situation in the learning and teaching process, both on the learning by roleplay technique and show-and-tell technique.

The Instruments of Collecting Data

The data were taken by doing observation completed with the rubric of scoring sheet instrument concerning with the students' speaking performance on 4-1 Likert scale. The instrument on the blueprint of scoring speaking skills based on the speaking skills proficiency categories by Brown (2004) was adapted, implemented, and summarized below.

Table 2. The Summary of Blueprint of Scoring Speaking Skills Performance

\begin{tabular}{cccc}
\hline Basic & Indicator & Assessed & Score \\
No & Aspects & & \\
\hline
\end{tabular}




\begin{tabular}{|c|c|c|c|c|}
\hline \multirow{3}{*}{1} & \multirow{3}{*}{$\begin{array}{l}\text { Speaking } \\
\text { English } \\
\text { correctly } \\
\text { and } \\
\text { appropriate } \\
\text { ly }\end{array}$} & $\begin{array}{l}\text { Speaking English with appropriate } \\
\text { and correct vocabulary }\end{array}$ & Vocabulary & $1-4$ \\
\hline & & $\begin{array}{c}\text { Speaking English with good } \\
\text { pronunciation }\end{array}$ & Pronunciation & $1-4$ \\
\hline & & Speaking English fluently & Fluency & $1-4$ \\
\hline
\end{tabular}

\section{Notes of the Score:}

a. Vocabulary

1 : Speaking English with no correct and appropriate vocabulary

2 : Speaking English without quite correct and appropriate vocabulary

3 : Speaking English with correct vocabulary even though it has not been appropriate yet with the situation and condition

4: Speaking English with correct vocabulary and in accordance with the situation and condition

b. Pronunciation

1 : Errors in pronunciation are frequent

2 : Accent is intelligible though often quite faulty

3 : Errors never interfere with understanding and rarely disturb the native speaker

4 : Errors in pronunciation are quite rare

c. Fluency

1 : The utterance is not fluent, not clear and it misses the meaning

2 : The utterance is not very fluent, not very clear and it effects the meaning

3 : The utterance is not too fluent and sometimes still uses Bahasa accent

4: Able to speak fluently and clearly almost like native speakers

Validity of the Instrument

In this study, the researcher used content validity in which the validity of the instrument was determined or judged by an expert of language education as the validator. And the validator of the instrument, in this case, was Drs. Suhaini Muhammad Saleh, M.A., an English lecturer of Yogyakarta State University.

Reliability of the Instrument

A good instrument must be reliable, that is to say that the instrument used to measure something frequently produces the same data (consistent). This research used inter-rater reliability. After that the result of the inter-rater reliability was then examined by Pearson Product Moment correlation technique to find out the correlation degree between the rater (scorer) 1 and the rater 2, in this case was the observer (researcher) and the English teacher of grade 5 Demak, Emi Prihastuti, S.Pd. If the result of both raters showed a significant correlation, it could be concluded that both raters have similar understanding to the instruments used. If the instruments were examinably 
reliable, they could be then used by the researcher for collecting the data or doing experiment. It was supported by the table of correlation coefficient as follows.

Table 3. Table of Correlation Coefficient

\begin{tabular}{cc}
\hline Interval of Coefficient & Level of Correlation \\
\hline $0.00-0.199$ & Very low/Slight \\
\hline $0.20-0.399$ & Low \\
\hline $0.40-0.599$ & Moderate \\
\hline $0.60-0.799$ & High \\
\hline $0.80-1.000$ & Very High \\
\hline \multicolumn{2}{c}{ (Guilford, 1956) }
\end{tabular}

While the summary of counting the instrument reliability is shown on the table 4 as follows.

Table 4. The Result Summary of Instrument Reliability Test

\begin{tabular}{lcc}
$\begin{array}{c}\text { Assessed } \\
\text { Aspects }\end{array}$ & $\begin{array}{c}\text { Correlation Coefficient } \\
\text { of } \\
\text { Rater 1 and Rater 2 }\end{array}$ & $\begin{array}{c}\text { Level of } \\
\text { Correlation }\end{array}$ \\
\hline Fluency & 0.920 & Very High \\
\hline Vocabulary & 0.846 & Very High \\
\hline Pronunciation & 0.843 & Very High \\
\hline Total & 0.923 & Very High \\
\hline
\end{tabular}

Table 4 noted that all scores of Pearson correlation were higher than significance level at 0.01 . Correlation of scoring of fluency by rater 1 and rater 2 was 0.920 , of vocabulary was at 0.846 , and of pronunciation was at 0.923 meaning that there was a very high and significant correlation between the scoring of rater 1 and the scoring of rater 2 of each all aspects. Therefore, the instrument can be used for collecting data.

The Technique of Analyzing Data

The technique of analyzing data used in this research was inferential statistic technique, that was one way analysis of variance (one way ANOVA). "One way ANOVA test is used to examine the differences in more than two groups" (Seliger \& Shohamy, 1989). If the F value of ANOVA test is significant, it will be followed by doing Scheffe test on SPSS 17.00 for windows program to investigate how significant the difference of effectiveness among those three techniques namely role-play, show-and-tell, and lecturing. Before analyzed, the data must fulfil some conditions included randomized sample, normalized distribution of the data, and having homogeneity of the sample variance. In 
short, as the requirement of ANOVA, the researcher must do pretest statistically included normality and homogeneity test.

Normality

Normality test is done by using Kolmogrov Smirnov scale in the level of significance at 0.05 helped by SPSS 17.00 for windows program. If the test result is normal, the statistic accounting result can be generalized at the research population. The normality test is done to the pretest and posttest data in experimental and control groups. To examine the normality of data, the researcher can see the score of $p$. If $p>0.05$, meaning that the data distribute normally. The result of asumption test of normality which is done to the pretest and posttest at the experimental and control groups shows that $p>$ 0.05 so that all data in this research were distributed normally.

Homogeneity

To know whether the variance score of population is similar or not, the researcher does homogeneity test by checking Levene Statistics in SPSS 17.00 for windows program. In this case, the researcher examines the variances homogeneity based on as follows: (1) if the probability (Sig.) score is $<0.05$ meaning that the variances are not homogeneous, and (2) if the probability (Sig.) score is $>0.05$ meaning that the variances are homogeneous.

The hypothesis proposed to examine the homogeinity of variance is as follows:

$\mathrm{H}_{0}$ : Variance of variable is homogeneous

$\mathrm{Ha}$ : Variance of variable is heterogeneous

$\mathrm{H}_{0}$ will be accepted if $\operatorname{sig}>0.05$.

The test of normality and homogeneity assumption as the requirements for analysis had been fulfilled. It indicated that the researcher then could analyze the variances by using one-way ANOVA. The posttest result of two experimental groups and control group with ANOVA was as the following. 
Trable 5. The Output of ANOVA

\begin{tabular}{|l|c|c|c|c|c|}
\hline & $\begin{array}{c}\text { Sum of } \\
\text { Squares }\end{array}$ & df & $\begin{array}{c}\text { Mean } \\
\text { Square }\end{array}$ & F & Sig. \\
\hline $\begin{array}{l}\text { Between } \\
\text { Groups }\end{array}$ & 5068.137 & 2 & 2534.068 & 12. & .000 \\
\hline $\begin{array}{l}\text { Within } \\
\text { Groups }\end{array}$ & 15033.205 & 76 & 197.805 & 811 & \\
\hline Total & 20101.342 & 78 & & & \\
\hline
\end{tabular}

In the table 5 , it shows that the F score was 12.811 with Sig. $(p)<0.05$ $(0.00<0.05)$, meaning significant. From that of score $(0.00<0.05)$, it can be concluded that there was significant difference of effectiveness among the learning using technique of role-play, show-and-tell, and lecturing in learning the speaking skills of the grade 5 students of SD Budi Mulia Dua Yogyakarta.

After that, because the result of ANOVA test stated significant, then the Scheffe test was done. The summary of Scheffe test was shown as the following in table 6 .

Table 6. The Summary of Scheffe Test

\begin{tabular}{|c|c|c|c|c|c|c|}
\hline \multirow[b]{2}{*}{$\begin{array}{l}\text { (I) } \\
\text { Technique }\end{array}$} & \multirow[b]{2}{*}{$\begin{array}{l}\text { (J) } \\
\text { Technique }\end{array}$} & \multirow{2}{*}{$\begin{array}{c}\text { Mean } \\
\text { Difference } \\
\text { (I-J) }\end{array}$} & \multirow[b]{2}{*}{$\begin{array}{l}\text { Std. } \\
\text { Error }\end{array}$} & \multirow[b]{2}{*}{ Sig. } & \multicolumn{2}{|c|}{$95 \%$ Confidence Interval } \\
\hline & & & & & $\begin{array}{l}\text { Lower } \\
\text { Bound }\end{array}$ & $\begin{array}{l}\text { Upper } \\
\text { Bound }\end{array}$ \\
\hline \multirow[t]{2}{*}{$\operatorname{Exp} 1$} & Expt2 & $9.76923^{\circ}$ & 3.90074 & .049 & .0299 & 19.5086 \\
\hline & Control & $19.55983^{\circ}$ & 3.86446 & .000 & 9.9111 & 29.2086 \\
\hline \multirow[t]{2}{*}{ Exp2 } & Exp1 & $-9.76923^{\circ}$ & 3.90074 & .049 & -19.5086 & -.0299 \\
\hline & Control & $9.79060^{\circ}$ & 3.86446 & .046 & .1419 & 19.4393 \\
\hline \multirow[t]{2}{*}{ Control } & $\operatorname{Exp} 1$ & $-19.55983^{*}$ & 3.86446 & .000 & -29.2086 & -9.9111 \\
\hline & $\operatorname{Exp} 2$ & $-9.79060^{*}$ & 3.86446 & .046 & -19.4393 & -.1419 \\
\hline
\end{tabular}

Based on the table of One-Way ANOVA and the summary of Scheffe test result to role-play technique and show-and-tell technique, it was found that the probability score or sig. ( 2 tailed) was $0.049<0.05$. So it can be concluded then that there was significant difference of effectiveness between the use of role-play technique and show-and-tell technique. Whereas the score of mean difference was 9.76923. Those data mean that the application of learning by using role-play technique was more effective than the use of show-and-tell technique in the learning of grade 5 students' speaking skills. 
Based on the table of One-Way ANOVA and Scheffe test result between role-play technique and lecturing technique, it was found that the probability score was 0.000, lower than the significance level at 0.05. Because sig. 0.049 $<0.05$, so it could be concluded then that there was significant difference of effectiveness between the use of role-play technique and lecturing or conventional technique. Whereas the score of mean difference was 19.55983, meaning that the application of learning by using role-play technique was more effective than the use of conventional technique in the learning of grade 5 students' speaking skills.

Whereas based on the table of One-Way ANOVA and Scheffe test result between show-and-tell technique and conventional technique, it was found that the probability score was 0.046, lower than the significance level at 0.05. Because Sig $<0.05$, so it could be concluded then that there was significant difference of effectiveness between the use of show-and-tell technique and conventional technique. Whereas the score of mean difference was 9.79060, meaning that the application of learning by using show-and-tell technique was more effective than the use of conventional technique in the learning of grade 5 students' speaking skills.

As a whole, based on the output of Scheffe test, it could be stated that the learning by using role-play technique was the most effective among those three techniques in the learning of grade 5 students' speaking skills. Showand-tell was the next technique and the conventional or lecturing technique was the last one.

\section{CONCLUSION}

From the data analysis and the aforementioned discussion in the previous chapter, it can be concluded as follows:

First, the use of role-play and show-and-tell are effective in the speaking skills learning of grade 5 students of SD Budi Mulia Dua Yogyakarta. Based on the data analysis, it can be proved that the learning by using role-play and show-and-tell technique is effective in the speaking skills learning of grade 5 students of SD Budi Mulia Dua Yogyakarta. It is shown by the output score of 
independent samples test at 0.05 alpha level in which it is higher than the significance score (Sig.) or $p<0.05$ meaning that there has been significant difference of effectiveness after the treatments. In other words, the use of roleplay and show-and-tell technique in the learning can improve the score of students' speaking skills.

Second, role-play technique is more effective than show-and-tell in the speaking skills learning of grade 5 students of SD Budi Mulia Dua Yogyakarta. The Scheffe test shows that the score of probability is lower than the significance level at 0.05 with $\mathrm{F}=12.811$, meaning that the technique of roleplay is more effective than show-and-tell technique in the speaking skills learning of grade 5 students of SD Budi Mulia Dua Yogyakarta.

Based on the research findings, the researcher then recommends some suggestions. For teachers, they can apply the technique of role-play as an alternative method for improving the speaking skills of grade 5 students in SD Budi Mulia Dua Yogyakarta or other students from other primary schools which have the same characteristics as SD Budi Mulia Dua Yogyakarta. However, teachers can use other methods, strategies, approaches, and techniques to improve the speaking skills of grade 5 students if they are proved more effective than role-play technique. For students, in theoretical and practical aspects, role-play and show-and-tell are effective to improve students' speaking skills including their fluencies, pronunciations, and vocabularies. So it is recommended for them to use those of techniques to improve their speaking skills in the learning. For principals, the learning for improving speaking skills by using role-play and show-and-tell techniques are effective, so that principals can recommend their English teachers to use qualified and interesting techniques which can improve students' speaking skills. For researchers, they can do such an advanced study on role-play and show-and-tell to students of higher level education. It is because the researcher thinks that these techniques can be improved based on the students' age. Certainly the assessment of speaking skills does not only count for three criteria (fluency, pronunciation, and vocabulary), but also it counts for other aspects such as grammar and comprehension. 


\section{REFERENCES}

Aini, A., Andayani, \& Anindyarini, A. (2012). Mind-mapping method to improve the speaking skills of elementary school students. BASASTRA: Jurnal Penelitian Bahasa, Sastra Indonesia dan Pengajarannya Volume 1 Nomor 1, Desember 2012, 125-137.

Brown, H. D. (2001). Teaching by principles: An interactive approach to language pedagogy. (2nd ed.). New York: Pearson Education Company.

Brown, H. D. (2004). Language assessment: Principles and classroom practices. San Fransisco: Longman.

Cameron, L. (2001). Teaching languages to young learners. Cambridge: Cambridge University Press.

Campbell, D., \& Stanley, J. (1966). Experimental and quasi-experimental designs for research. Chicago: Rand McNally College Pub. Co.

Creswell, J. (2008). Educational research. New Jersey: Pearson Education, Inc.

Dailey, K. (1997). Sharing centers: An alternative approach to show and tell . Early Childhood Education Journal. Vol. 24., No. 4., 223-227.

Ellis, G., \& Brewster, J. (2002). The primary English teacher's guide (new edition). Essex: Penguin English.

Fraenkel, J., \& Wallen, N. (2008). How to design and evaluate research in education (7th ed.). New York: McGraw-Hill.

Guilford, J. (1956). Fundamental statistics in psychology and education. . New York: McGraw Hill.

Harmer, J. (2003). The practice of English language teaching. Harlow: Pearson Education Limited.

Hornby, A. (1995). Oxford advanced learner's dictionary (5th ed.). Oxford: Oxford University Press. 
Joyce, B., Weil, M., \& Calhoun, E. (2009). Models of teaching (8th ed.) Translation by Achmad Fawaid \& Ateilla Mirza). Yogyakarta: Pustaka Pelajar.

Ladousse, G. (2000). Role play. Oxford: Oxford Univeristy Press.

McDonough, J., \& Shaw, C. (2003). Materials and methods in ELT (2nd ed.): A teacher's guide. Melbourne: Blackwell Publishing.

Nunan, D. (2005). Designing tasks for the communicative classroom. Cambridge: Cambridge University Press.

Paul, D. (2003). Teaching English to children in Asia. Hong Kong: Longman.

Paulston, C. B., \& Bruder, M. N. (1976). Teaching English as a second language: Techniques and procedures. Winthrop Publishers.

Random House Incorporation. (2010). Random House Kernerman Webster's College Dictionary. Tel Aviv: K Dictionaries Ltd. .

Ratminingsih, N. M. (2010). Drills and total physical response: an attempt to enhance young learners' oral communicative competence. Jurnal Pendidikan dan Pengajaran, Jilid 43, Nomor 18, Juli 2010, 149 - 158.

Richards, J., \& Renandya, W. (2002). Methodology in Language teaching: An anthology of current practice. New York: Cambridge University Press.

Rivers, W. (1983). Speaking in many tongues: Essays in foreign-language teaching (3rd ed.). Cambridge: Cambridge University Press.

Seliger, H., \& Shohamy, E. (1989). Second language research methods. Oxford: Oxford University Press.

Supartinah. (2010). The effectiveness of applying role-play and telling picture story technique to improve Javanese speaking skills of grade V students in SDN Lempuyangan Yogyakarta. Yogyakarta: Yogyakarta State University. 
Walter, E. (. (2008). Cambridge advanced learner's dictionary (third edition). Cambridge: Cambridge University Press.

Wiersma, W., \& Jurs, S. G. (2009). Research methods in education: An introduction (9th ed.). Boston: Pearson Education. 